\title{
Determinants of the continuous operations of micro and small enterprises during COVID-19 pandemic in Ethiopia
}

\author{
Erstu Tarko Kassa* (1)
}

\section{${ }^{*}$ Correspondence:}

erstu0910@gmail.com

Woldia University, Woldia,

Ethiopia

\begin{abstract}
The main objective of this study is to assess determinant factors for the continuous operations of micro and small enterprises during COVID-19 pandemic. The study adopted a cross-sectional design, with both descriptive and explanatory research design. To achieve the objectives of the study, 276 respondents were selected from 890 micro and small enterprise owners. The sample of the study was selected through proportional stratified random sampling technique from the business types (manufacturing, construction, urban agriculture, service and trade). To collect the primary data, questionnaires were dispatched to owners/operators of micro and small enterprises. The collected data were analyzed through descriptive, correlation and regression analysis techniques. The finding of the study revealed that people and administrative factors, regulatory factors, economic factors, partnerships, leadership of owner have a positive relationship to micro-small enterprise continuous operations during COVID19 pandemic with the value of $r=0.457,0.558,0.572,0.519$ and 0.654 , respectively. The study regression analysis result assured that partnership, economic factors, and leadership of the owner has a positive statistical significant effect on the continuous operations of the micro and small enterprise during COVID-19 pandemic with the value of $(p<0.05)$. The researcher recommended that strenghtening partnership with stakeloders and excersing best leadership practices are essential to ensure the continuous operations of the micro and small enterpreses.
\end{abstract}

Keywords: Micro and small enterprises, Continuity, COVID-19, Partnership, Leadership

\section{Introduction}

Micro and small enterprise (hereafter MSE) has great contributions for the community, government and graduates or job seekers by creating job opportunities and enhance revenue for the individuals (Rascón \& Velázquez, 2019). MSEs are contributing a lion share of the country economy to bring sustainable development in developed and developing countries, and able to bring a paradigm shift for a new and more sustainable way of production and consumption (Alemu \& Dame, 2017; Karanja et al., 2013; Ruchkina et al., 2017).

The recent studies results show that micro and small enterprises contribute $60 \%$ of GDP and over $70 \%$ of total job opportunities in developing countries, and also above $95 \%$

(C) The Author(s), 2021. Open Access This article is licensed under a Creative Commons Attribution 4.0 International License, which permits use, sharing, adaptation, distribution and reproduction in any medium or format, as long as you give appropriate credit to the original author(s) and the source, provide a link to the Creative Commons licence, and indicate if changes were made. The images or other third party material in this article are included in the article's Creative Commons licence, unless indicated otherwise in a credit line to the material. If material is not included in the article's Creative Commons licence and your intended use is not permitted by statutory regulation or exceeds the permitted use, you will need to obtain permission directly from the copyright holder. To view a copy of this licence, visit http:// creativecommons.org/licenses/by/4.0/. 
of employment and 70\% of GDP arise from MSE in the middle-income level countries (Abdissa \& Fitwi, 2016). Even though, the contribution of MSEs become higher and significant in both developing and developed countries these enterprises have been ached by different disasters in different countries. Their continuity became in question by natural disasters and other catastrophic events (Samantha, 2018).

After the outbreak of COVID-19, the continuity of MSEs in different countries is not a smart way. The pandemic smashes the country's economy and has an impact on the output, disruption of supply chain, inflation, decline transportation services, investment declined, jobless citizens increased, and social impacts like poverty gender inequality. The pandemic forced the countries to closes non-essential businesses, bring bankruptcy for business, and laid off permanent and blue collar workers (Elenev et al., 2020; Techno Serve Business Solution to Poverty, 2020).

The COVID-19 pandemic has an impact on the MSEs, a response measure should be taken by the concerned bodies. It has an indirect impact on the Ethiopian MSE in the current situation due to the slow spread of the virus. The UNDP-supported Entrepreneurship Development Centre (EDC) has conducted a quick survey to assess the impact MSEs have sustained as a result of COVID-19, their perception of potential future impacts, and their recommendations for remedial actions. The data gathered from 60 EDC clients in Addis Ababa and in the four regional states where EDC has regional coordination offices (Amhara, Oromia, SNNPS, and Tigray) show that, on average, an enterprise lost Birr 142,654 (USD 4755) in monthly sales (80\%) and Birr 21,643 (USD 721) in monthly income. Based on these figures, EDC clients alone, totaling 32,250 enterprises, have lost Birr 4.6 billion in monthly sales and Birr 704 million in monthly income during March 2020 (ILO, 2020; UN, 2020).

Previous studies indicate that the continuity of MSEs affected by financial sources, taxation, administration barriers, age, gender, scholarship, marital status, economic sectors, family tradition, increase income, profession, experience, flexible schedule, unemployment, financial support, problem, problems related with the sale, workers, wage finance, knowledge empowerment, capacity building, and location of the business (Alvarado Lagunas. et al., 2018; Ruchkina et al., 2017; Uchehara, 2019).

Based on the above discussion, the researcher was motivated to know which factors considerably affected MSEs' continuity in this critical time of the COVID-19 outbreak. Among the factors, people and administrative factors, regulatory factors, economic factors, partnerships, the leadership of owner, and government support are examined under this study.

By considering the factors two objectives have been set by the researcher. The first objective is to evaluate to what extent people and administrative factors, regulatory factors, economic factors, partnerships, and leadership of owner affect the continuity of MSEs during COVID-19 and the second one is to examine the relationship between people and administrative factors, regulatory factors, economic factors, partnerships, and leadership of owner with MSE continuity during COVID-19 pandemic.

\section{Review of related literatures}

Sustainability of MSE is the way to nonstop able learning, adapt and develop, renew, reconstruct, and reorient to maintain a lasting and distinctive position in the market by offering buyers above-average value today and in the future through organic variation 
constituting business models, and arising from the creation of new opportunities, objectives, and responses to them, while balancing the interests of different groups. Sustainable business development involves the application of sustainability principles to business operations. It is a variety of things like ecological sustainability, social sustainability, or sustained economic growth (Grudzewski et al, 2010; Szczepańska-Woszczyna \& Kurowska-Pysz, 2016).

\section{MSEs' continuity strategy}

According to empirical studies when micro and small enterprises are unable to prepare a continuity plan, especially during disaster or crisis $75 \%$ of the business will fail due to natural and manmade disasters (Cook, 2015). During the crisis time, effort should be expended to prepare a contingency and a business plan that may help to mitigate, and restore micro and small businesses caused by the crisis (Cook, 2015; Quarantelli et al., 2007).

There is also a strategy to survive the micro-small enterprises, namely marketing innovation through fast distribution, proper promotion, and fair prices (Fabeil et al., 2020). Many studies on crisis management that help to save MSEs include at least three standard phases, i.e., pre-crisis, during crisis, and post-crisis (Fabeil, et al., 2019; Leinonen, 2018), which are usually further divided into more detailed phases. These may include risk assessment, prevention, preparedness, response, recovery, and learning, which are particularly used in the field of disaster reduction and business continuity as suggested by the notion of ISO standard (Leinonen, 2018). This notion is used in analyzing the results of the current study to understand the impact of the crisis on business strategy throughout each phase of movement control order (MCO) amid COVID-19 in Malaysia.

MSEs and industry relationships between the estimated risk of contagion at work and the adoption of robots, to test the hypothesis that robotization may facilitate social distancing and lower the risk of contagion. The analysis, which includes various controls of possible automation-related confounding factors and addresses possible issues of indignity, provides evidence that industries employing more robots per worker in production tend to exhibit a lower risk of contagion due to COVID-19 (Piccolo et al., 2020).

The other study done in Mexico, micro-business owners continue operating their micro-business with a strong relationship with family traditions, entrepreneurship benefits, and a low paying job. The variables identified in this study considerably affect the success of micro and small enterprises (Alvarado Lagunas et al., 2018).

Properly administering and managing the newly established business is crucial to survive and save the life of the business and has a positive effect. On the other hand, lack of study regarding pandemic outbreak that affects the enterprises negatively and the age of business, record and borrowing were seen as significant in predicting business success (Alemu \& Dame, 2017; Fabeil et al., 2020).

In a study conducted by Kamunyu and Theuri (2017), they identified factors that affect the performance of women micro and small enterprises. Among the factors that affect the business, performance is inadequate capital, lack of business skills, and lack of access to credit facilities. A survey result shows that during COVID-19 pandemic $40 \%$ could 
not set a timeframe to continue due to wages and rents cost and 64\% of MSE faced for bankruptcies by a labor shortage and supply chains and consumer demand.

According to Bouey (2020), physical space and unable to getting shop is a challenge for supermarkets, traditional food markets, restaurants, car dealers, movie theaters, gyms, and bars, suffered significant losses. The corona pandemic forced governments to lockdown was very severe in Italy, with a reduction in the value of potential output produced peaking at $69 \%$ for the construction and real estate and $63 \%$ for mechanics. As a result, GDP is expected to drop by around 10\% in 2020 (Navaretti et al., 2020).

A study was done in China, South Korea, Japan, Italy, the UK, and the four largest states in the US to collect data related with work and living situations, income, behavior, beliefs about the COVID-19 pandemic, and exposure to the virus, socio-demographic characteristics and pre-pandemic health characteristics. The data indicate that calibrating certain parameters used in economic and epidemiological models, or for documenting the impact of the crisis on individuals, both in financial and psychological terms and for understanding the scope for policy intervention by documenting how people have adjusted their behavior as a result of the COVID-19 pandemic and their perceptions regarding the measures implemented in their countries (Michèle et al., 2020). Increased business start-ups, use of indigenous technologies, business, and customer growths help to enhance and improved to achieve sustainable rural development by operating MSEs (Uchehara, 2019).

\section{Conceptual framework of the study}

See Fig. 1.

\section{Methods of the research}

In this study cross-sectional method with both descriptive and explanatory research design has been used. Because the data were collected at one shot of time and described as it is by using descriptive research design and explanatory research design helps to explain the cause-and-effect relationship between independent variables with the dependent variable.

The target population of the study was 890 enterprise owners in the Woldia city administration. From the total population 214 owners engaged in the manufacturing sector, 96 construction, 75 urban agriculture, 238 services, and the remaining 267 were working in the trade sector (WTVEDO, 2020).

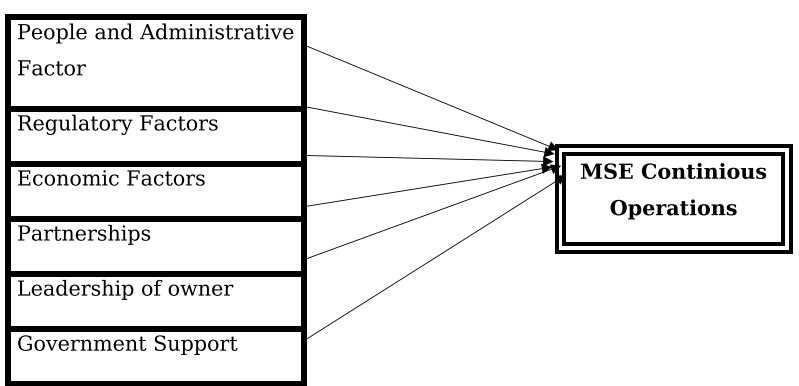

Fig. 1 Conceptual framework of the study. Source Model proposed by the researcher (2020) 
To participate in respondents from this study, the researcher used simple random sampling techniques from the targeted population of the study. This sampling technique allows for all target population equal chance to participate in this study. The sample size also has been determined by using Yamane (1967) formula and proportional technique from each business type. Thus, the formula is described as follows:

$$
n=\frac{N}{1+N(e)^{2}}
$$

where $N=$ target population, $n=$ sample size, $e=$ error term.

$$
n=\frac{890}{1+890(0.05)^{2}}
$$

$$
n=276 .
$$

Based on the sample size the respondents have participated proportionally as follows from each business type. As shown in Table 1, the total population was divided as strata based on the business type owners engaged in.

\section{Data collection and measures}

The data were collected by using a questionnaire technique from the respondents. All questionnaires contain a Likert scale. The source and the items are described as following in Table 2.

\section{Model specification}

As indicated by Kothari (2004), standard multiple linear regressions being one family of statistical techniques, is used to explore the relationship between one dependent variable and a number of independent variables or predictors simultaneously enabling to get answers regarding how well a set of variables is able to predict a particular outcome and which variable in a set of variables is the best predictor of an outcome. Thus, this study allowed multiple regression analysis used to understand by how much each independent variable (people and administrative factors, regulatory factors, economic factors, partnerships, leadership of owner, and government support) explains the dependent variable (continuous operations of micro and small enterprises during COVID-19 pandemic).

Regression equation of performance on selected variables:

Table 1 Sample size of the study

\begin{tabular}{lcc}
\hline Business type & Number of MSE & Sample size \\
\hline Manufacturing & 214 & 66 \\
Construction & 96 & 30 \\
Urban agriculture & 75 & 23 \\
Service & 238 & 74 \\
Trade & 267 & 83 \\
Total & 890 & 276 \\
\hline
\end{tabular}

Source TVEDO (2020) 
Table 2 Questionnaire items, measures and sources

\begin{tabular}{|c|c|c|c|}
\hline Construct & Number of items & Measurement & Source \\
\hline PAF & $\begin{array}{l}\text { PAF1, PAF2, PAF3, PAF4, PAF5, PAF6 } \\
\text { and PAF7 }\end{array}$ & Likert scale (5 points) & ILO (2020) \\
\hline Partnerships & PA1,PA2,PA3,PA4,PA5,PA6 and PA7 & Likert scale (5 points) & ILO (2020) \\
\hline Economic factors & $\mathrm{EF} 1, \mathrm{EF} 2, \mathrm{EF} 3, \mathrm{EF} 4, \mathrm{EF} 5, \mathrm{EF} 6$, and $\mathrm{EF} 7$ & Likert scale (5 points) & ILO (2020) \\
\hline Regulatory factors & $\mathrm{RF} 1, \mathrm{RF} 2, \mathrm{RF} 3$, and RF4 & Likert scale (5 points) & ILO (2020) \\
\hline Leadership of the owner & $\mathrm{LO} 1, \mathrm{LO} 2, \mathrm{LO} 3$, and LO4 & Likert scale (5 points) & $\begin{array}{l}\text { Szczepańska- } \\
\text { Woszczyna } \\
(2016)\end{array}$ \\
\hline Government support & $\mathrm{GS1} 1, \mathrm{GS} 2, \mathrm{GS} 3, \mathrm{GS} 4, \mathrm{GS} 5$, and GS6 & Likert scale (5 points) & $\begin{array}{l}\text { Tadesse } \\
(2020)\end{array}$ \\
\hline $\begin{array}{l}\text { Continuous operation of micro and } \\
\text { small enterprises during COVID-19 } \\
\text { pandemic }\end{array}$ & MSEC1, MSEC2, MSEC3, and MSEC4 & Likert scale (5 points) & $\begin{array}{l}\text { Tadesse } \\
\text { (2020) }\end{array}$ \\
\hline
\end{tabular}

$$
Y=\beta_{0}+\beta_{1} X_{1}+\beta_{2} X_{2}+\beta_{3} X_{3}+\beta_{4} X_{4}+\beta_{5} X_{5}+\beta_{6} X_{6}+e,
$$

where $Y$ is a dependent variable-MSEs' continuity during COVID-19 pandemic; $\mathrm{X}_{1}=$ people and administrative factors, $\mathrm{X}_{2}=$ regulatory factors, $\mathrm{X}_{3}=$ economic factors, $\mathrm{X}_{4}=$ partnerships, $\mathrm{X}_{5}=$ leadership of owner, and $\mathrm{X}_{6}=$ government support, are the explanatory variables. $\mathrm{B} 0$ is the intercept term-constant which is equal to the mean if all slope coefficients are $\beta_{0} . \beta_{1}, \beta_{2}, \beta_{3}, \beta_{4}, \beta_{5}$, and $\beta_{6}$, are the coefficients associated with each independent $t$ variable which measures the change in the mean value of $Y$, per unit change in their respective independent variables and e is an error term.

\section{Results and discussion}

\section{Demographic variables analysis}

Table 3 indicates that $36.6 \%$ of respondents are female and the remaining $63.4 \%$ are male. From the total respondents, $7.6 \%$ were below the age of $20,66.7 \%$ are between 21 to 30 years, $24.3 \%$ are between 31 and 40 years and the remaining $1.4 \%$ are above 40 years. Regarding business type respondents engaged in almost $23.9 \%$ are engaged in the manfacturing sector, $10.9 \%$ of respondents have participated in the construction business sector, $8.3 \%$ from urban agriculture, $26.8 \%$ are service business owners, and $30.01 \%$ are engaged in the trade sector.

\section{Descriptive statistics of independent and dependent variables}

As indicated in Table 4, the mean result of the variables of the study for people and administrative factors, partnerships, economic factors, regulatory factors, leadership of owner, and government support has a value of 3.59, 3.36,2.89,3.01, 3.33, and 3.72, respectively. As per the cutoff point set by Al-Sayaad et al. (2006), the mean result for people and administrative factor and government support is indicated "Agree" for Likert scale level, the remaining variables indicated "neutral" level. Thus, the study done by Rascón and Velázquez (2019) the mean result of people and administrative factors is not similar to this study result. 
Table 3 Demographic variables and business type

\begin{tabular}{lll}
\hline Variables & Frequency & Percent \\
\hline Sex & & \\
Male & 175 & 63.4 \\
Female & 101 & 36.6 \\
Total & 276 & 100.0 \\
Age & & 7.6 \\
$<20$ years & 21 & 66.7 \\
$21-30$ years & 184 & 24.3 \\
$31-40$ years & 67 & 1.4 \\
$>40$ years & 4 & 100.0 \\
Total & 276 & 23.9 \\
Types business engaged in & & 10.9 \\
Manufacturing & 66 & 8.3 \\
Construction & 30 & 26.8 \\
Urban agriculture & 23 & 30.1 \\
Service & 74 & 100 \\
Trade & 83 & \\
Total & 276 &
\end{tabular}

Source Own survey (2020)

Table 4 Descriptive statistics

\begin{tabular}{llll}
\hline Variables & Mean & Std. deviation & $\begin{array}{l}\text { Response decision: } \\
\text { Al-Sayaad et al. } \\
\text { (2006) }\end{array}$ \\
\hline People and administrative factors & 3.5963 & 0.69579 & Agree \\
Partnership & 3.3639 & 0.82890 & Neutral \\
Economic factors & 2.8980 & 1.01719 & Neutral \\
Regulatory factors & 3.0100 & 1.11238 & Neutral \\
Leadership of owner & 3.3342 & 0.99677 & Neutral \\
Government support & 3.7271 & 0.75141 & Agree \\
MSE continuous operations & 3.4239 & 0.82026 & Agree \\
\hline
\end{tabular}

Source Own survey (2020)

\section{Reliability statistics}

To check the consistency and stability of the collected data, the reliability test is crucial. In this regard, the reliability test was conducted for six independent variables and one dependent variable of the study. The Cronbach's alpha as shown in Table 5 for people and administrative factors, partnership, economic factor, regulatory factor, the leadership of owner, government support, and MSE continuity are 0.826, 0.833, 0.861, 0.860, $0.877,0.795$ and 0.757 , respectively. As stated by Zikmund (2011), scales with a constant between 0.80 and 0.95 are considered to have very good reliability. Scales with a constant between 0.70 and 0.80 are considered to have good reliability, and a value between 0.60 and 0.70 indicates fair reliability. Therefore, the study variables reliability is above 0.7 , which is a good reliability result as stated by Zikmund (Table 6). 
Table 5 Reliability

\begin{tabular}{lll}
\hline Variables & Cronbach's Alpha & No. of items \\
\hline People and administrative factors (PA) & 0.826 & 7 \\
Partnership (PR) & 0.833 & 7 \\
Economic factor (EF) & 0.861 & 7 \\
Regulatory factor (RF) & 0.860 & 4 \\
Leadership of owner (LO) & 0.877 & 4 \\
Government support (GS) & 0.795 & 6 \\
MSE continuous operations MSCO) & 0.757 & 4
\end{tabular}

Source Own survey (2020)

\section{Correlation analysis}

We can understand that except the government support other five independent variables has a positive relationship with micro and small enterprise continuity during COVID19 pandemic. The variables " $r$ " value of people and administrative factors, regulatory factors, economic factors, partnerships, leadership of owner which has a positive relationship with the value of $r=0.457,0.558,0.572,0.519$, and 0.654 , respectively, with a $p$-value of less than 0.05 .

Table 7 presents how much of the change in the explained variable is explained by the model. The multiple coefficients of determination denoted as $R^{2}$ is 0.493 . The value of the adjusted $R^{2}$ indicates that $48.2 \%$ of the variance in the dependent variable was explained by the model.

When we come to the variables incorporated under in this study partnership, economic factors, and leadership of owner significantly $(p<0.05)$ influence positively the continuous operations of the MSEs COVID-19 pandemic, as indicated in Table 8. However, the remaining people and administration factors, regulatory factors, and government support do not significantly $(p>0.05)$ influence positively the continuous operation of MSEs during the COVID-19 pandemic.

Table 6 Correlations

\begin{tabular}{llllllll}
\hline & PA & PR & EF & RF & LO & GS & MSCO \\
\hline PA & 1 & $0.594^{* *}$ & $0.556^{* *}$ & $0.440^{* *}$ & $0.513^{* *}$ & 0.024 & $0.457^{* *}$ \\
PR & $0.594^{* *}$ & 1 & $0.561^{* *}$ & $0.508^{* *}$ & $0.600^{* *}$ & 0.025 & $0.558^{* *}$ \\
EF & $0.556^{* *}$ & $0.561^{* *}$ & 1 & $0.735^{* *}$ & $0.659^{* *}$ & 0.068 & $0.572^{* *}$ \\
RF & $0.440^{* *}$ & $0.508^{* *}$ & $0.735^{* *}$ & 1 & $0.679^{* *}$ & 0.026 & $0.519^{* *}$ \\
LO & $0.513^{* *}$ & $0.600^{* *}$ & $0.659^{* *}$ & $0.679^{* *}$ & 1 & 0.041 & $0.654^{* *}$ \\
GS & $0.024^{*}$ & 0.025 & 0.068 & 0.026 & 0.041 & 1 & -0.027 \\
MSCO & $0.457^{* *}$ & $0.558^{* *}$ & $0.572^{* *}$ & $0.519^{* *}$ & $0.654^{* *}$ & -0.027 & 1
\end{tabular}

**. Correlation is significant at the 0.01 level (2-tailed). Source Own survey (2020)

Table 7 Model summary

\begin{tabular}{lllll}
\hline Model & $R$ & $R^{2}$ & Adjusted $R^{2}$ & Std. error of the estimate \\
\hline 1 & $0.702^{a}$ & 0.493 & 0.482 & 0.59026 \\
\hline
\end{tabular}

a Predictors: (constant), GS, PA, RF, PR, LO, EF 
Table 8 Coefficient

\begin{tabular}{|c|c|c|c|c|c|}
\hline \multirow[t]{2}{*}{ Model } & \multicolumn{2}{|c|}{ Unstandardized coefficients } & \multirow{2}{*}{$\begin{array}{l}\text { Standardized } \\
\text { coefficients } \\
\text { Beta }\end{array}$} & \multirow[t]{2}{*}{$T$} & \multirow[t]{2}{*}{ Sig } \\
\hline & B & Std. error & & & \\
\hline (Con) & 1.350 & 0.261 & & 5.180 & 0.000 \\
\hline PAF & 0.041 & 0.068 & 0.035 & 0.611 & 0.542 \\
\hline PA & 0.193 & 0.060 & 0.195 & 3.229 & 0.001 \\
\hline EF & 0.148 & 0.058 & 0.184 & 2.565 & 0.011 \\
\hline RF & -0.002 & 0.051 & -0.002 & -0.036 & 0.971 \\
\hline LO & 0.331 & 0.055 & 0.402 & 6.032 & 0.000 \\
\hline $\begin{array}{l}\text { Government sup- } \\
\text { port }\end{array}$ & -0.068 & 0.048 & -0.062 & -1.426 & 0.155 \\
\hline
\end{tabular}

Source Own survey (2020)

\section{Discussion}

From the study variable government support has a negative relationship with MSE continuous operation during COVID-19 pandemic with the value of -0.027 with a $p$ value of greater than 0.05 . The correlation between people and administrative factors is similar to the finding of Abdissa and Fitwi (2016) with the result of $r=0.342$. The other study was done by Rascón and Velázquez (2019) people and administrative factors had a positive relationship with other study variables with the value of $r=0.60$ with significant $p$ value. This study result is similar to this study. Another study was done by Cherkos et al. (2018) legal and leadership with MSE performance result in a high correlation with Pearson correlation values of $r=0.988$ and 0.939 , respectively. This indicates that there is a similar result to this study's findings.

The effect analysis finding revealed that leadership of the owner has positive influence on MSEs' continuous operation during COVID-19 pandemic. This result is similar to the finding of Szczepańska-Woszczyna (2014). The role of leadership skills is crucial to sustain and enhance the performance of MSE in challenging times (Alemayehu \& Gecho, 2016; Gelgelu, 2018; Kamunyu \& Theuri, 2017).

In another study done by Tekola and Gidey (2019), weak human resources development schemes, dependency on government are the factors that influence the sustainability of Ethiopian micro and small enterprises. This result contradicts the present study's findings because the people and administration factors and government supports are not significant under this study. Economic factors have a positive influence on MSEs' continuous operation during COVID-19 pandemic.

\section{Conclusion}

This study intended to investigate the factors determine the MSEs' continuity during COVID-19 pandemic in Woldia City administration. From the factors incorporated under this study, people and administrative factors, regulatory factors, economic factors, partnerships, and leadership of owner have a positive relationship with the continuity of MSEs' continuity during COVID-19 pandemic with the Pearson correlation value of $r=0.457,0.558,0.572,0.519$ and 0.654 , respectively, with $p$ value of less than 
0.05. And also from the identified variables partnership, economic factors, leadership of owners have a positive influence on the continuity of MSE during COVID-19 pandemic with a $p$ value of less than 0.05 . The researcher recommended that strenghtening partnership with stakeloders and excersining best leadership practices are essential to ensure the continuous operations of the micro and small enterpreses.

\section{Abbreviations}

MSE: Micro and small enterprises; PA: People and administrative factors; PR: Partnership; EF: Economic factor; RF: Regulatory factor; LO: Leadership of owner; GS: Government support; MSCO: Micro and small enterprises continuous operations.

\section{Acknowledgements}

N/A.

\section{Authors' contributions}

The research was done independently. I have carried out the whole work of the study. The author read and approved the final manuscript.

\section{Funding}

The author did not receive funding from any organization.

Availability of data and materials

All data are included in the manuscript and available on hand too.

\section{Declarations}

Competing interests

The author declares that there are no competing interests.

Ethics approval and consent to participate

During data collection, respondents gave verbal consent for the data collectors and showed their willingness to fill the dispatched questionnaires.

\section{Consent for publication}

Not applicable.

Received: 22 February 2021 Accepted: 19 October 2021

Published online: 01 November 2021

\section{References}

Abdissa, G., \& Fitwi, T. (2016). Factors affecting performance of micro and small enterprises in South West Ethiopia: The case of Bench Maji, Sheka, and Kefa zones. Global Journal of Management and Business Research, 16, 1.

Alemayehu, D., \& Gecho, Y. (2016). Determinants of micro and small enterprises growth: The case of Durame Town, Kembata Tembaro Zone, Southern Nations and Nationalities and Peoples Region, Ethiopia, 2016. International Journal of Business and Economics Research, 5(5), 161-175.

Alemu, K. S., \& Dame, D. B. (2017). Determinants of micro and small enterprises success: The case of ambo town, Ethiopia? Journal of Asian and African Social Science and Humanities, 3(1), 86-96.

Al-Sayaad, J., Rabea, A., \& Samrah, A. (2006). Statistics for economics and administration studies. Dar Hafez.

Alvarado Lagunas, E., Dávila Aguirre, M. C., \& Vázquez Zacarías, M. A. (2018). Factors that influence the continuity and survival of a micro-business in Mexico. Contaduría y Administración, 63(3), 1-20.

Barrett, R. (2020). Wisconsin farmers forced to dump milk as coronavirus slams a fragile dairy economy. Milwaukee Journal Sentinel. Retrieved from https://eu.jsonline.com/story/money/2020/04/01/coronavirus-forces-dairy-farmers-dumpmilk-wisconsin-covid-19/5108609002/

Belot, M., Choi, S., Jamison, J. C., Papageorge, N. W., Tripodi, E., \&Van den Broek-Altenburg, E. (2020). Six-country survey on COVID-19.

Bouey, J. (2020). Assessment of COVID-19's Impact on small and medium-sized enterprises: Implications from China: Testimony of Jennifer Bouey, before the US House Committee on Small Business, March 10, 2020. Rand Corporation.

Caselli, M., Fracasso, A., \& Traverso, S. (2020). Mitigation of risks of Covid-19 contagion and robotisation: Evidence from Italy. Covid Economics, 17, 174-188.

Cherkos, T., Zegeye, M., Tilahun, S., \& Avvari, M. (2018). Examining significant factors in micro and small enterprises performance: Case study in Amhara region, Ethiopia. Journal of Industrial Engineering International, 14(2), 227-239.

Cook, J. (2015). A six-stage business continuity and disaster recovery planning cycle. SAM Advanced Management Journal, $80(3), 22-33$.

Elenev, V., Landvoigt, T., \& Van Nieuwerburgh, S. (2020). Can the covid bailouts save the economy? (No. w27207). National Bureau of Economic Research. 
Fabeil, N. F., Pazim, K. H., \& Langgat, J. (2020). The impact of Covid-19 pandemic crisis on micro-enterprises: Entrepreneurs' perspective on business continuity and recovery strategy. Journal of Economics and Business, 3, 2.

Gelgelu, D. G. (2018). Assessment of the factors affecting the performance of micro and small scale enterprise: The case of Wolkite town, Guraghe zone, Southern Ethiopia. Journal of Development and Agricultural Economics, 10(6), 192-199.

Grudzewski, W. M., Hejduk, I. K., Sankowska, A., \& Wańtuchowicz, M. (2010). Sustainability w biznesie, czyli przedsiębiorstwo przyszłości. Zmiany Paradygmatów i Koncepcji Zarzq̨dzania, Poltext, Warszawa, 2010, 26.

Gujarati, D. (2004). Basic econometrics. McGraw-Hill.

Hashem, N. M., González-Bulnes, A., \& Rodriguez-Morales, A. J. (2020). Animal welfare and livestock supply chain sustainability under the COVID-19 outbreak: An overview. Frontiers in Veterinary Science, 7, 679.

International Labour Organization. (2020). COVID-19 and enterprise briefing note [12]. n.

Kamunyu, C. W., \& Theuri, F. S. (2017). Factors affecting growth of women owned small and medium enterprises in Kenya: A survey of Women-Led SMEs in South Coast Ukunda. International Journal of Social and Development Concerns, 19(3), 60-66.

Karanja, T., Muturi, P., Mukabi, M., \& Kabata, D. (2013). Small business management. International Journal of Business and Social Science, 4, 16

Kothari, C. R. (2004). Research methodology: Methods and techniques. New Age International.

Leinonen, T., Viikari-Juntura, E., Husgafvel-Pursiainen, K., Virta, L. J., Laaksonen, M., Autti-Rämö, I., \& Solovieva, S. (2018). Labour market segregation and gender differences in sickness absence: Trends in 2005-2013 in Finland. Annals of Work Exposures and Health, 62(4), 438-449.

Longenecker, J. G., Petty, J. W., Palich, L. E., \& Hoy, F. (2013). Small business management. Nelson Education.

Navaretti, G. B., Calzolari, G., Dossena, A., Lanza, A., \& Pozzolo, A. F. (2020). In and out lockdowns: Identifying the centrality of economic activities. Covid Economics, 17, 189-204.

Piccolo, R., Bruzzese, D., Mauro, C., Aloia, A., Baldi, C., Boccalatte, M., \& Esposito, G. (2020). Population trends in rates of percutaneous coronary revascularization for acute coronary syndromes associated with the COVID-19 outbreak. Circulation, 141(24), 2035-2037.

Quarantelli, E. L., Lagadec, P., \& Boin, A. (2007). A heuristic approach to future disasters and crises: New, old, and inbetween types. In H. Rodríguez, E. L. Quarantelli, \& R. R. Dynes (Eds.), Handbook of disaster research (pp. 16-41). Springer.

Rascón, O. C. A., \& Velázquez, R. P. (2019). Factors that determine the closure or jeopardize the continuity of a micro and small enterprise. Organizations and Markets in Emerging Economies, 10(1), 78-91.

Ruchkina, G., Melnichuk, M., Frumina, S., \& Mentel, G. (2017). Small and medium enterprises in the context of regional development and innovations. Journal of International Studies, 10, 4.

Samantha, G. (2018). The impact of natural disasters on micro, small and medium enterprises (MSMEs): A case study on 2016 flood event in Western Sri Lanka. Procedia Engineering, 212, 744-751.

Szczepańska-Woszczyna. (2014). SMEs managers a need for competence. Acta Educationis Generalis, 4(1), 1-16.

Szczepańska-Woszczyna, K., \& Kurowska-Pysz, J. (2016). Sustainable business development through leadership in SMEs. Engineering Management in Production and Services, 8(3), 57-69.

Techno Serve Business Solution to Poverity. (2020, June). COVID-19 and Entrepreneurs in the Developing World . Supporting Business Survival and Recovery. 1777 N Kent Street | Suite 1100 | Arlington, VA 22209.

Tadesse, M. C. (2020). Factor affecting the growth and continuity of micro and small enterprise in Robe Town. European Journal of Business and Management, 12(16), 21-31.

Tekola, H., \& Gidey, Y. (2019). Contributions of micro, small and medium enterprises (MSMEs) to income generation, employment and GDP: Case study Ethiopia. Journal of Sustainable Development, 12(3), 46-81.

Uchehara, F. (2019). Effect of Micro, Small and Medium Enterprises (MSMEs) in Sustainable Rural Development in Nigeria. Small and Medium Enterprises (MSMEs) in Sustainable Rural Development in Nigeria (June 30, 2019).

United Nations Ethiopia. (2020, May). Socio-Economic Impact of COVID-19 in Ethiopia .

Vincent ter Beek V., \& McCullough, C. (2020, April). Covid-19 crisis hits US pig production hard. Pig Progress. Retrieved from https://www.pigprogress.net/World-of-Pigs1/Articles/2020/4/Covid-19-crisis-hits-US-pig-production-hard-576238E/

Woldia City Administration Technique and Vacational Enterprise Development Office (WTVEDO). (2020). Annual Report 2012E.C. Woldia.

World Bank. (2020). COVID-19 (Coronavirus) Drives Sub-Saharan Africa Toward First Recession in 25. Retrieved from https:// www.worldbank.org/en/news/press-release/2020/04/09/covid-19-coronavirus-drives-sub-saharan-africa-towardfirst-recession-in-25-years

Zikmund, B. C. (2011). Business research methods. 8.

\section{Publisher's Note}

Springer Nature remains neutral with regard to jurisdictional claims in published maps and institutional affiliations. 